\title{
Methodology to carry out an analysis of damage caused by wear of blades of axial compressor on a marine gas turbine
}

\section{Metodología para realizar un análisis de los daños causados por el desgaste de los álabes del compresor axial de una turbina de gas marina}

\author{
VILLAGRÁN-VILLEGAS，Luz Yazmín†*1,2，SIORDIA-VÁSQUEZ，Xóchitl²，PATIÑO-ORTIZ, \\ Miguel $^{1}$ and VELÁZQUEZ-MARTÍNEZ, Víctor ${ }^{2}$ \\ ${ }^{I}$ Instituto Politécnico Nacional, Escuela Superior de Ingeniería Mecánica y Eléctrica, Sección de Estudios de Posgrado e \\ Investigación, Unidad Profesional Adolfo López Mateos "Zacatenco", Edificio 5 3er. Piso, Col. Lindavista, C.P. 07300, \\ Ciudad de México. \\ ${ }^{2}$ Universidad Veracruzana, Facultad de Ingeniería Mecánica Eléctrica, Av. Venustiano Carranza S/N, Revolución, C. P. \\ 93390, Poza Rica; Veracruz, México.
}

ID $1^{\text {st }}$ Author: Luz Yazmín, Villagrán-Villegas / ORC ID: 0000-0003-3860-2923, CVU CONACYT ID: 96365

ID $1^{\text {st }}$ Co-author: Xóchitl, Siordia-Vásquez / ORC ID: 0002-8472-8001, CVU CONACYT ID: 1036998

ID $2^{\text {nd }}$ Co-author: Miguel, Patiño-Ortiz / ORC ID: 0000-0002-5630-8077, CVU CONACYT ID: 167388

ID $3^{\text {rd }}$ Co-autor: Víctor, Velázquez-Martínez / ORC ID: 0000-0001-5343-8346, CVU CONACYT ID: 799141

DOI: $10.35429 /$ JOTI.2021.15.5.1.7

Received January 12, 2021; Accepted June 24, 2021

\section{Abstract}

The objective of this research was to reduce cost of maintenance in this equipment. Analysis on a blade of gas turbine was performed, which was in operation on an offshore platform. Compressor blade was exposed to a severe damage by the impact of particles and environmental pollutants such as salts, sands and sulphurs. In first stage of this analysis, a visual inspection with a borescope was effected. Images analysis was used to determine the typical failure modes. A tribological characterization was carried out. Chemical composition of the material of blades was obtained. Scanning electron microscopy (SEM) was used to measure chemical properties and evaluate degradation of surfaces of blades after 30,000 service hours. The points, where there are the points in which failures take place. Results showed wear modes were originated by a severe stinging action. Also, large craters, similar to those observed in solid particle erosion, were developed by at normal impact. In the same way it could be found some localized areas with corrosion and irregular scratches like plowing action, was observed; these are the points in which failures take place.

Gas turbine blades, Non-destructive testing, Borescope, Optical 3Dscanner.

\begin{abstract}
Resumen
El objetivo de esta investigación fue reducir el costo de mantenimiento de este equipo. Se realizó un análisis en un álabe de turbina de gas, que se encontraba en operación en una plataforma costa afuera. El àlabe del compresor fue expuesto a un daño severo por el impacto de partículas y contaminantes ambientales como sales, arenas y azufres. En la primera etapa de este análisis, se realizó una inspección visual con un boroscopeo. Se utilizó el análisis de imágenes para determinar los modos de falla típicos. Se realizó una caracterización tribológica. Se obtuvo la composición química del material del álabe. Se utilizó microscopía electrónica de barrido (SEM) para medir las propiedades químicas y evaluar la degradación de las superficies de los álabes después de 30.000 horas de servicio. Los puntos, donde están los puntos en los que se producen los fallos. Los resultados mostraron que los modos de desgaste se originaron por una acción punzante severa. Además, se desarrollaron grandes cráteres, similares a los observados en la erosión de partículas sólidas, con un impacto normal. De igual forma se pudo encontrar algunas áreas localizadas con corrosión y raspaduras irregulares como acción de arado; estos son los puntos en los que se producen las fallas.
\end{abstract}

Alabes de Turbina de gas, Pruebas nodestructivas, Boroscopeo,Escanner 3D

Citation: VILLAGRÁN-VILLEGAS, Luz Yazmín, SIORDIA-VÁSQUEZ, Xóchitl, PATIÑO-ORTIZ, Miguel and VELÁZQUEZ-MARTÍNEZ, Víctor. Methodology to carry out an analysis of damage caused by wear of blades of axial compressor on a marine gas turbine. Journal of Technical Invention. 2021. 5-15:1-7

*Correspondence to Author (e-mail: yvillagran@uv.mx)

$\dagger$ Researcher contributing as first author. 


\section{Introduction}

The environment has a relatively passive role in the operation cycle of gas turbine; there are certain atmospheric conditions that can affect operation and life of gas turbines, in oil and gas platforms, entry of solid particles (see Figure 1) in gas turbines is unavoidable [1].

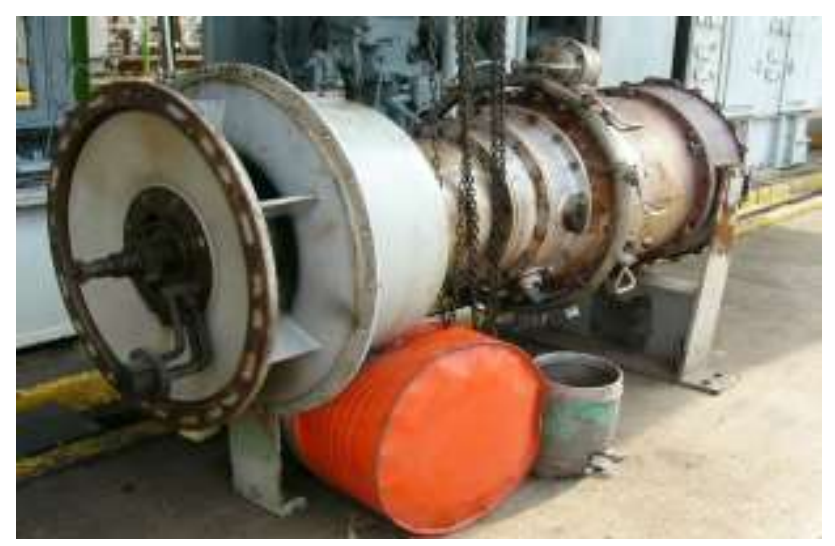

Figure 1 Gas turbine inlet air

The selection of materials in their design plays an important role in achievement of a greater efficiency and a safer and more costeffective operation [2]. Metallurgical and mechanical points of view in most common faults of gas turbine's blades are considered. Lifespan of a blade is reduced due to operating environment and high mechanical and thermal stresses, where two or more factors typically act simultaneously [3]. Most common degradation mechanisms are contamination and pitting, clearing between rotor and stator, and erosion of leading and trailing edge of blade of hot and cold part of gas turbine.

Degradation is mainly caused by: inlays, corrosion, hot corrosion, oxidation, erosion, abrasion, particles melting and mechanical degradation. Research on turbine's blades starts with visual observations, optical microscopy, scanning electron microscopy, fractography analysis, metallography, structural analysis and hardness tests. In Centaur 40 gas turbine (see Figure 2), the most common degradation mechanisms are: airfoil (blade) fouling and pitting (loss of flow profile caused by corrosion and surface deposits); opening of blade clearances and leading and trailing edge erosion (caused by mechanical solid and liquid impacts on rotor blades).
Several mechanisms cause degradation of compressor blades, for example: fouling, corrosion, erosion, abrasion, particle fusing and mechanical degradation [4].

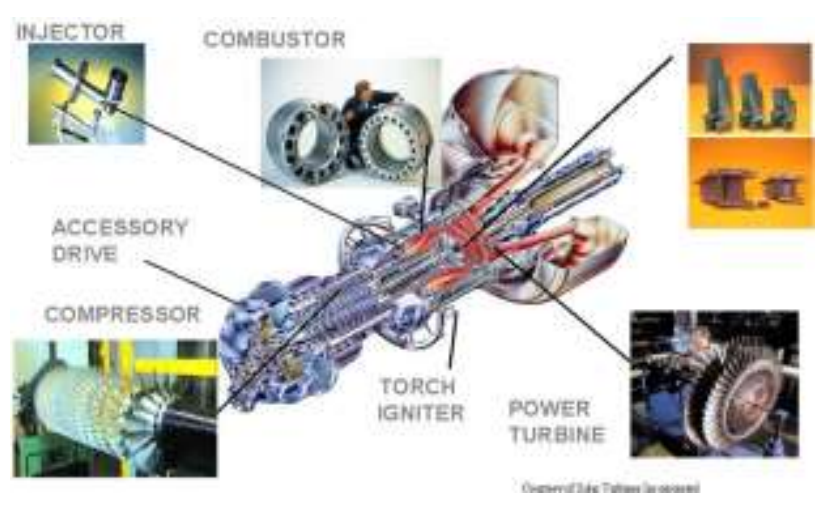

Figure 2 C40 gas turbine

Note: Adapted "Gas turbine degradation. Turbomachinery Laboratory”(p. 2), Kurz R. , 2014. Turbomachinery Laboratory

The most commonly used materials in gas turbine's blades are titanium or nickel super alloys and tungsten-molybdenum alloys; its assembly on rotor requires special care, paying special attention to optimum angle [5], some of the materials commonly used for manufacture of turbine's blades are martensitic stainless steels 403 or $403 \mathrm{Cb}$ [6], with a chromium content of $12 \%$

Blades operate at great vibratory forces, which requires sufficient resistance to fatigue; in particular, they must be manufactured with careful processes to support wear and resonance conditions, as well as to function optimally depending on pressure, temperature and viscosity conditions of fluid.

Axial compressor as the power turbine are formed by a certain number of stages, each stage involves a blade's disc, each blade of axial compressor in Centaur 40 gas turbine, inlet air gas turbine is room temperature $\left(15^{\circ} \mathrm{C}\right.$ sea level) and increases its temperature when it is compressed, reaching $1,800{ }^{\circ} \mathrm{C}$ after passing through combustion chambers. Centaur 40 gas turbine consists of 11 stages in axial type air compressor, pressure ratio is 10.3: 1 and air flow inlet is $18.7 \mathrm{~kg} / \mathrm{sec}(41.3 \mathrm{lb} / \mathrm{sec})$. Variable blades begin to open when the Pcd (Pressure compressor discharge) reaches approximately 32 psi (gp) and fully open when Pcd reaches approximately $76.5 \mathrm{lb} /$ in2 (gauge) [7]. 


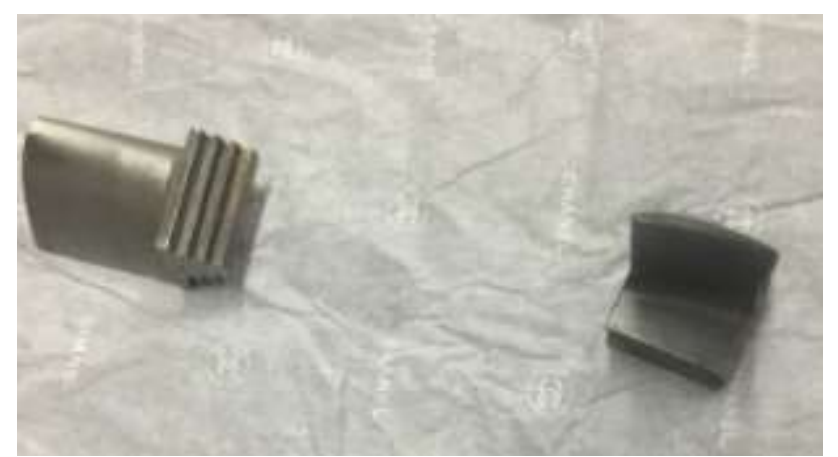

Figure 3 7th. Stage's blade, Rotor Axial Compressor

A study of wear damage of a seventhstage's blade of axial compressor of a gas turbine (see Figure 3) was carried out. Manufacturer recommends routine maintenance at 30,000 hours to reduce chances for shutdown of gas turbine. In this study, the C40 gas turbine at 24,000 hours (shutdown) in field and out of service after 30,000 hours was analysed. This gas turbine was operating in Campeche City, Mexico (see Table 2), in a very aggressive environment, where entry of solid particles is unavoidable.

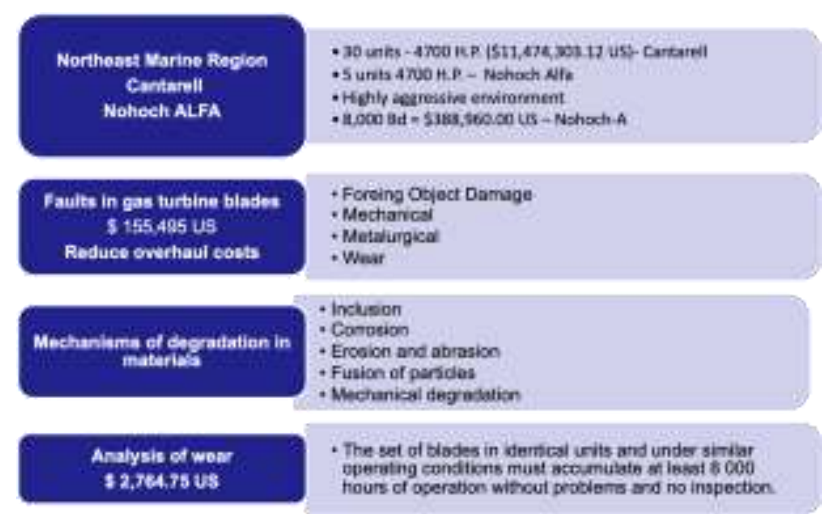

Figure 4 Operating condition of gas turbine in Campeche, Mexico

This paper proposes a methodology to carry out an analysis of damage caused by wear of axial compressor's blades in a gas turbine.

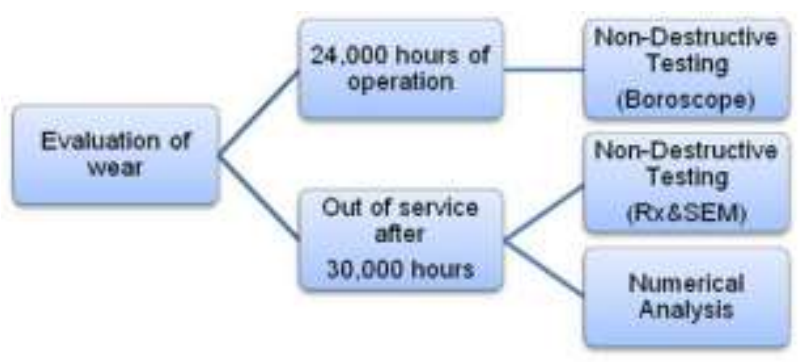

Figure 5 Evaluation of wear
Work was developed in three stages. In first one, a thorough visual inspection of gas turbine's blade was carried out, an analysis of borescope images of surfaces of vanes was carried out in site, and second stage: microstructural tests were carried out on blade. In second stage, a sample to obtain chemical composition of material was analysed, and roughness to know surface degradation of the same was measured; Scanning Electron Microscopy (SEM) and Rx to identify wear mechanisms in several sample was used. Analysis on trailing edge was performed, leading edge and central part of blade.

\section{Methodology}

\section{Visual examination}

Borescope test is a primary diagnostic method for turbo machinery maintenance; it is an inspection test that includes notification of the condition of equipment and effective programming of any necessary maintenance intervention. C40 gas turbine has four ports, where borescope can be introduced (Figure 5). Internal inspections are necessary to determine if wear or thermal erosion is present. Additionally, these inspections will take into account any damage caused by the impact of foreign objects (FOD), or if corrosion has occurred, and allow internal components to be assessed for thermal deterioration, fractures or distortion.

Corrosive attacks on aerodynamic surfaces can also be detected by borescope inspection.

A borescope inspection verifies that:

- Damage is the result of a blade or nozzle being hit by an object that originates in first stages of gas turbine section and axial compressor or combustor.

- The area of impact damage is at or near the tip of blade and vibration is stable and does not exceed the limits. Then unit can be operated (until a replacement or a scheduled revision can be obtained) while is closely monitored. If damage of blade is between the root of blade and the middle of its body, regardless of level of vibration reached, the unit should not be restarted and should be checked. 
Corrosion on same parts of gas turbine's blade can be tolerated, however, if corrosion is evident at the tip of blade, the unit should be turned off and checked. If damage was the result of an object from within gas turbine stage (such as a turbine's blade portion or a nozzle surface), the unit should not be restarted.

Changes in dimensions of blade will affect natural frequency of the blades. The damage or loss of material that occurs at the tip of blade will increase natural frequency. If damage occurs at or near the root of blade, it weakens structurally and decreases its natural frequency. Natural frequencies of blades are above normal operating speed of a gas turbine. However, a reduction in natural frequency of blades could bring it closer to normal operating speed of the starter motor [8].

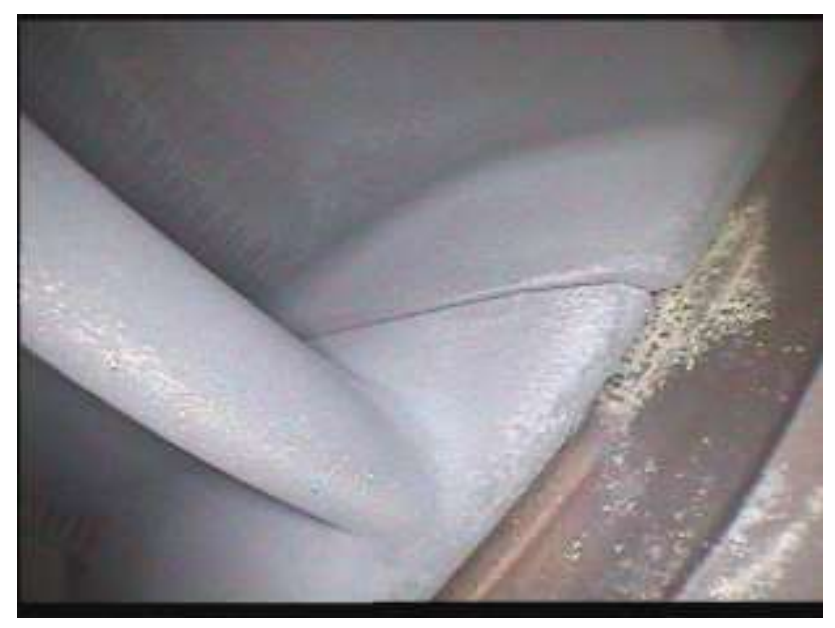

Figure 6 Boroscope test (24,000 hours)

In Borescope analysis, contamination in first stage of axial compressor was observed, it is a mixture of oil vapours that can prevent variable blades from opening or closing, which can lead to a low turbine performance and, even serious damage to turbines. The stage seventh of axial compressor has impregnated with dirt and debris, which is usually detergent and water used for washing of axial compressor's rotor (Figure 6 ), but this routine activity of maintenance is annual and technical engineer only carries out chemical analyses of water to detect metals in samples. In fact, his drag of solid particles by gas flow is another major problem during the operation of turbines. These foreign particles can either be deposited over turbine trail and blades (see Figure 1), causing wear and reducing efficiency of the turbine, or be launched at high velocities against blade surfaces, promoting formation of erosion pits in preferential areas, which can act as stress raisers [9-10].

\section{Non-destructive test: Rx \&SEM $(30,000$ hours)}

A characterization of surface of physical and chemical materials requires selection of an appropriate group of analytical and methodological techniques [11].

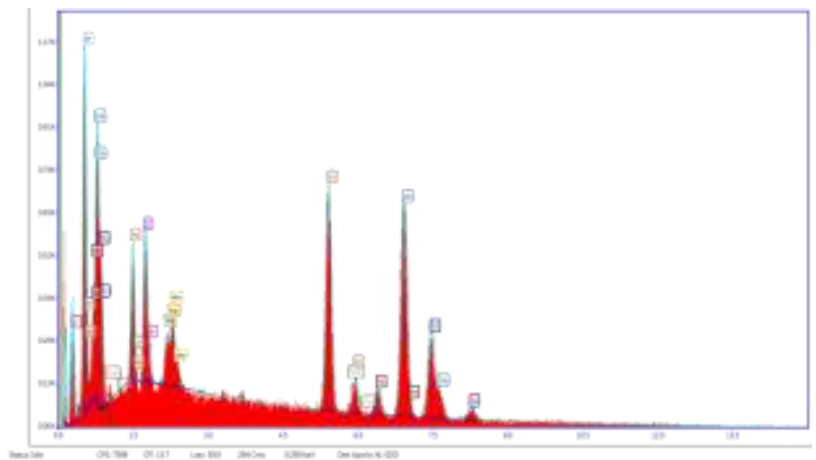

Figure 7 Chemical compositions used EDS Note. Adapted of Compressor turbine disk, VillagránVillegas Luz Yazmin, 2017

Energy dispersive X-ray (EDS) to obtain chemical composition was used. Chromium, Iron, Nickel and Carbon were detected and obtain quantitative analysis by Atomic Absorption Spectroscopy: chromium 17.9\%, nickel $11.4 \%$, molybdenum $0.01 \%$ and silicon $0.88 \%$.

A backscattered electron detector (BED) and Emission Scanning Electron Microscopy (JEOL JSM-7600F) to obtained SEM images were used. Tests were carried out to blade in leading and trailing edge (Figure 8) with field emission (show in Figure 9). In worn zone, 10 $\mathrm{kV}$ were applied and fourteen elements were found, such as chromium ( $\mathrm{Cr}$ ), nickel (Ni), molybdenum (Mo) and niobium ( $\mathrm{Nb}$ ). Percentages varied when evaluating a leading edge and another side, as shown Figure 9, but in analysis it was possible to identify the type of super alloy with 14 chemical elements in its composition. 


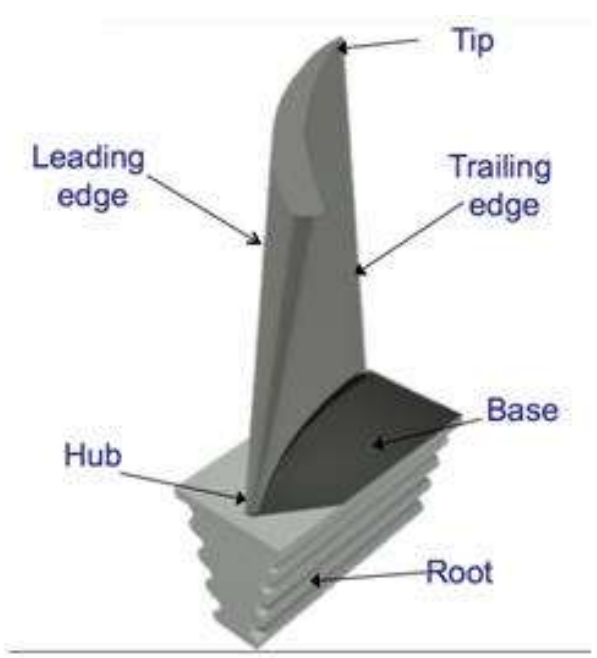

Figure 8 Parts of blade: leading edge, trailing edge, root, base and hub

Note. Analysis of Wear of gas turbine, Villagrán-Villegas Luz Yazmin, 2017
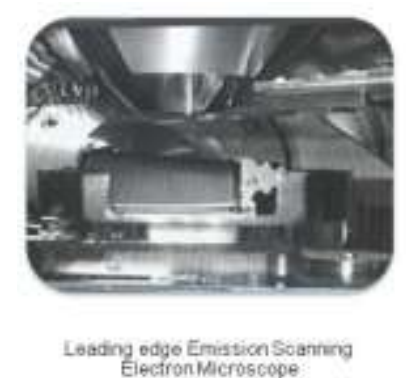

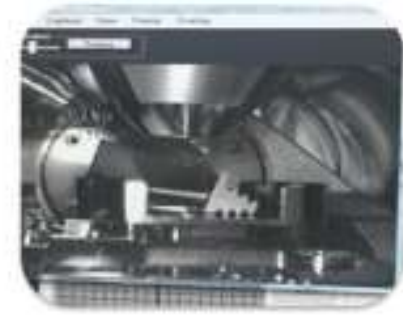

Traaing edje Emission Scanning
Ulectron Mcroscope
Figure 9 BED and Emission Scanning Electron Microscopy test

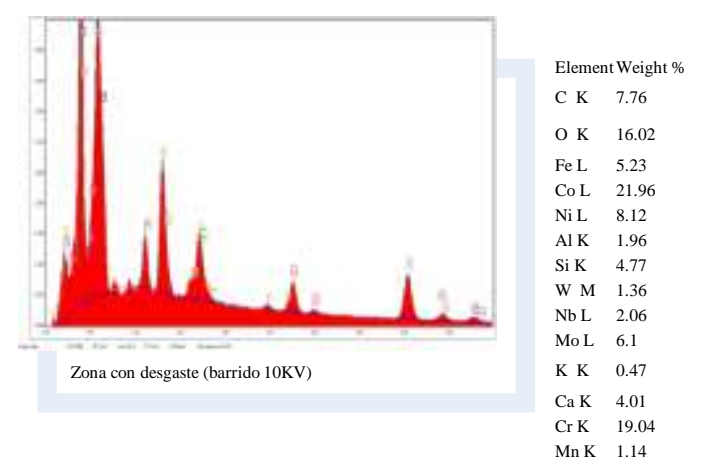

Figure 10 BED and Emission Scanning Electron Microscopy test

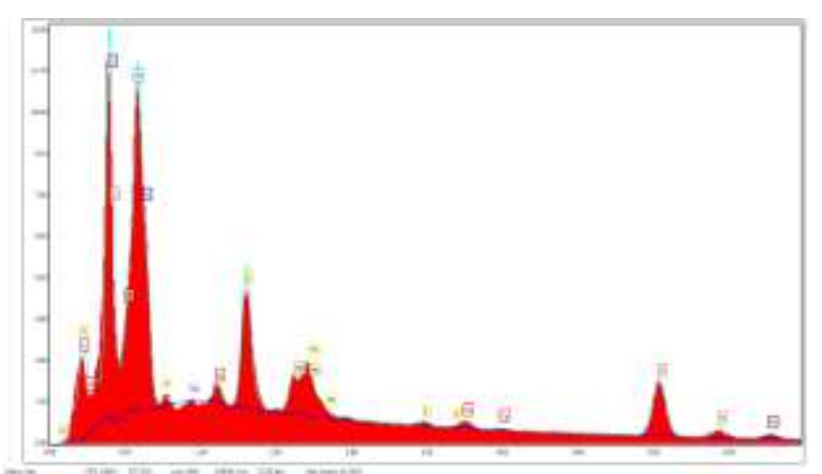

Figure 11 Chemical analysis in trailing edge 8 chemical elements and EDS graph
Elements such as cobalt (Co), nickel $(\mathrm{Ni})$, niobium $(\mathrm{Nb})$ and molybdenum (Mo), with exception of $\mathrm{Ni}$, these elements and weight percentages are close to martensitic stainlesssteel compositions [9].
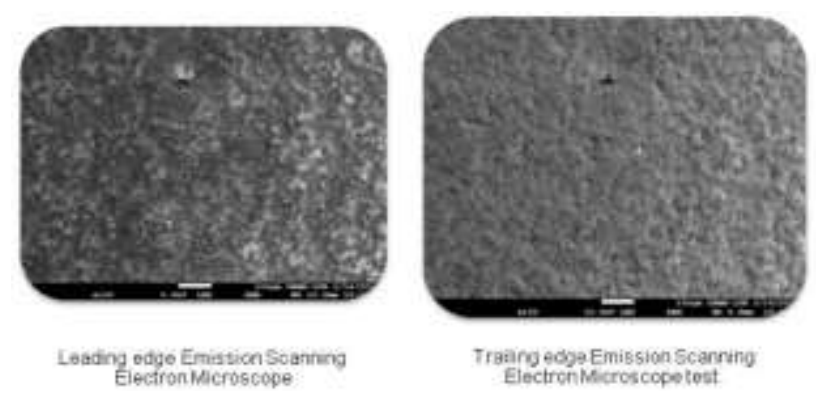

Figure 12 Worn region with $3 \mathrm{KV}$ and $15 \mathrm{KV}$ (JEOL JSM7600 SEM)

Note: Adapted "Study of wear damage in compressor turbine blades”(p. 65), Villagrán-Villegas L. , 2017

\begin{tabular}{|c|c|c|c|c|c|}
\hline $3 \mathrm{KV}$ & & & $15 \mathrm{KV}$ & & \\
\hline Element & Weight \% & Atomic \% & Element & Weight $\%$ & Atomic $\%$ \\
\hline$c k$ & 10.23 & 29.32 & C K & 8.46 & 25.22 \\
\hline $0 \mathrm{~K}$ & 8.95 & 19.25 & o K & 9.59 & 21.47 \\
\hline Al K & 2.71 & 3.45 & Al $\mathrm{K}$ & 2.84 & 3.76 \\
\hline Sik & 2.82 & 3.46 & Si K & 1.87 & 2.38 \\
\hline NbL & 1.93 & 0.72 & $\mathrm{KK}$ & 0.04 & 0.03 \\
\hline MoL & 1.83 & 0.66 & Ca K & 0.15 & 0.13 \\
\hline $\mathrm{crk}$ & 15.62 & 10.34 & $\pi i k$ & 0.34 & 0.25 \\
\hline $\mathrm{FeK}$ & 3.07 & 1.9 & $\mathrm{CrK}$ & 15.56 & 10.71 \\
\hline $\cos \mathrm{K}$ & 35.15 & 20.53 & $\mathrm{MnK}$ & 0.98 & 0.64 \\
\hline \multirow[t]{6}{*}{ Ni K } & 17.68 & 10.37 & Fe K & 3.09 & 1.98 \\
\hline & & & Co K & 35.06 & 21.3 \\
\hline & & & NiK & 17.75 & 10.83 \\
\hline & & & WL & 1.79 & 0.35 \\
\hline & & & $\mathrm{Nb} K$ & 0.38 & 0.15 \\
\hline & & & MoK & 2.11 & 0.79 \\
\hline
\end{tabular}

Figure 13 Worn region with $3 \mathrm{KV}$ and $15 \mathrm{KV}$ (JEOL JSM-7600 SEM)

In worn regions with $3 \mathrm{KV}$ and $15 \mathrm{KV}$ (Figure 12) showed different elements than those observed in worn surface. In zones 1 and 2 (Figure 13), new chemical elements appeared in EDS analysis such as carbon (C), oxygen (O), aluminum ( $\mathrm{Al})$, silicon $(\mathrm{Si})$, niobium $(\mathrm{Ni})$, molybdenum (Mo), chromium $(\mathrm{Cr})$, iron $(\mathrm{Fe})$, cobalt $(\mathrm{Co})$ and nickel $(\mathrm{Ni})$ and when applying $15 \mathrm{KV}$ new chemical elements appeared in EDS analysis such as carbon (C), oxygen (O), aluminium (Al), silicon $(\mathrm{Si})$, potassium $(\mathrm{K})$, calcium $(\mathrm{Ca})$, titanium $(\mathrm{Ti})$ chromium $(\mathrm{Cr})$, manganese $(\mathrm{Mn})$, iron $(\mathrm{Fe})$, cobalt $(\mathrm{Co})$, nickel $(\mathrm{Ni})$, Tungsten (W), niobium (Ni) and molybdenum (Mo), which could be due to introduced particles (contaminants) travelling in air intake or from hot corrosion (accelerated oxidation damage) due to corrosive deposits. There is evidence of aluminum, chromium and iron oxides in this region [12-13]. 


\section{Scanning electron microscopy analysis}

In this phase of scanning, two techniques to preparation of the sample were used, first one analysis in trailing edge (Figure 14) and then leading edge of the piece (Figure 16), which are shown below:

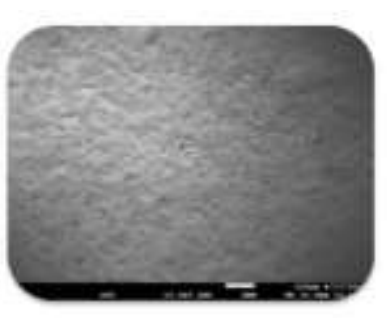

Irregutericertstion inlesding edge

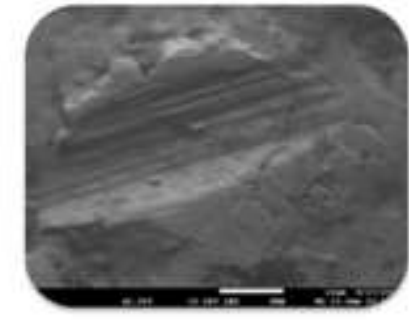

idertistion with moteriai pled-up:
Figure 14 Irregular indentation and material piled-up (trailing edge)

Note: Adapted "Study of wear damage in compressor turbine blades”(p. 88), Villagrán-Villegas L. , 2017

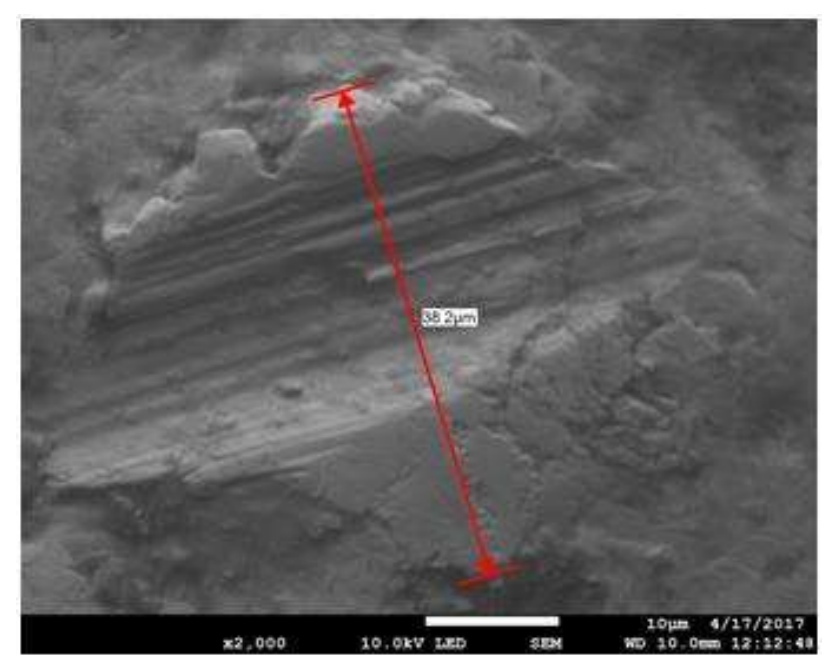

Figure 15 Cavity around $38.2 \mu \mathrm{m}$.
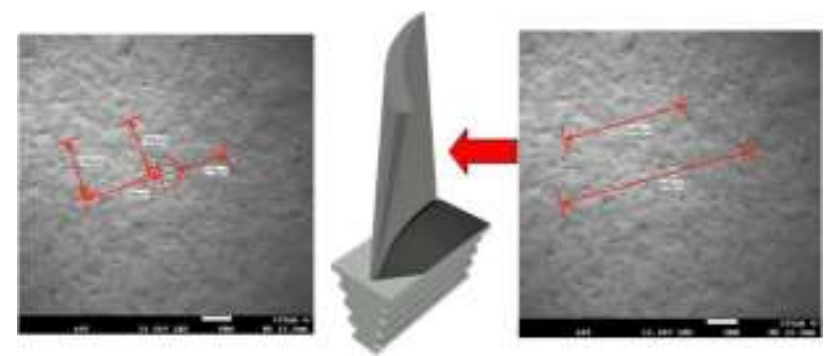

Figure 16 Trailing edge (Emission Scanning Electron Microscopy test)

Figure 16 in trailing edge, present irregular indentations were identified on surfaces around 176-268 $\mu \mathrm{m}$ length with material piled-up (lips) at sides and cavity around $38.2 \mu \mathrm{m}$ (see Figure 15), the result of subsequent particle impacts, which caused detachment of lips with trajectory around 408$648 \mu \mathrm{m}$.

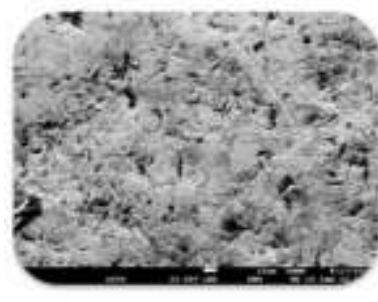

Large craters and grove (picushing
ocbori) in trating edige.

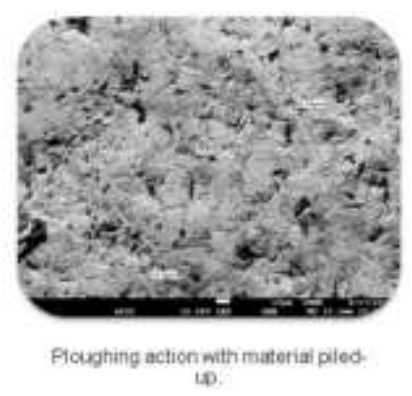

40.
Figure 17 Trailing edge (Emission Scanning Electron Microscopy test)

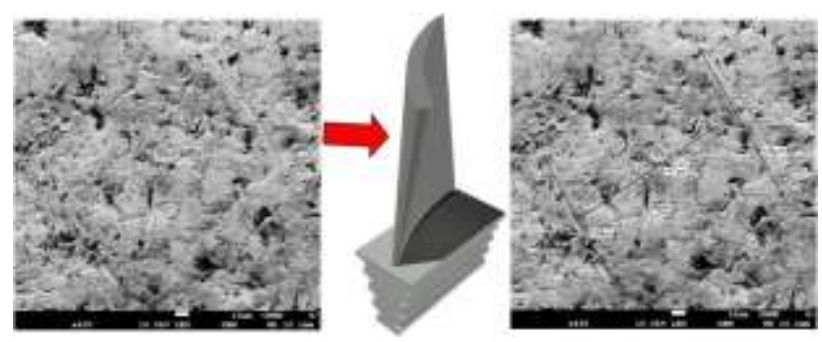

Figure 18 Leading edge (Emission Scanning Electron Microscopy test)

Images in Figures 17 and 18 in leading edge, which are characterized by large craters and grooves (ploughing action) of around 125$150 \mu \mathrm{m}$ length with material piled-up (lips) at sides around 4.7-15.2 $\mu \mathrm{m}$ length and in front of cavities, which is common in solid particle erosion, as specimens are impacted at oblique incident angles $\left(\alpha \leq 45^{\circ}\right)$ [14].

\section{Conclusions}

In this paper a methodology was developed to carry out analysis of damage caused by wear of blades of axial compressor on a gas turbine. Different types of analysis were carried out in trailing edge and leading edge of blade, where in the Emission Scanning Electron Microscopy analysis it was obtained that blades are manufactured from a chrome-based superalloy with chemical elements such as $\mathrm{Co}, \mathrm{Cr}, \mathrm{Ni}, \mathrm{Fe}$, $\mathrm{C}, \mathrm{Nb}$ and $\mathrm{Mo}$, likewise analysis showed degradation of surfaces in areas of higher air pressure mixed with particles.

In microstructural tests, wear mechanisms characterized by large craters and grooves were identified, wear remains incorporated in surfaces of zones, and mechanisms were presented such as corrosion damage, irregular cavities, wear debris, flattened foreign particles on surface and parallel grooves showing the trajectory of solid particle impacted on blade during its operation. 
Finally, this study shows the kind of damage caused by wear in axial compressor's blades on a gas turbine with some evidence of a witch corrosion and irregular scratches similar to plowing action, was observed. These are the points in which failures take place.

\section{References}

[1] Tabakoff, H. S. (1998). Blade Deterioration in a Gas Turbine Engine. (G. science, Ed.) International Journal of Rotating Machinery, 4 (4), p. 233-241.

[2] Pettit, F. S., \& Goward, G. W. (1981). High temperature corrosion and use of coatings for protection. Metallurgical Treatises, 1, p. 603619.

[3] Hutchings, I. (2003). Tribology (Vol. 1). (B. Heinemann, Ed.) London, London, UK: Elsevier Science.

[4] Kurz. (2014). Gas turbine degradation. Turbomachinery Laboratory, 1 (1), p. 36.

[5] NageswaraRao, M. (2011). Materials for Gas Turbines - An Overview, Advances in Gas Turbine Technology.Intech Europe, University Campus STePRi. Rijeka: Intech.

[6] Shilke, P. W. (2004). Advanced Gas Turbine Materials and Coatings. (Ge, Ed.) Ge Power, 1 (p. 356).

[7] Solar Turbines A Caterpillar Company. (2007). Curso de operación y mantenimiento rutinario (Vol. 1). San Diego, C.A., USA: Solar Turbines Incorporated.

[8] Giampaolo, A. (2006). Gas Turbine Handbook; Principles and practices (3a. ed., Vol. 1). (CRC, Ed.) BR, Florida, USA: The Fairmont press.

[9] Romero CA, Campos-Amezcua A. (2007) Numerical investigation of the solid particle erosion rate in a steam turbine nozzle. Appl. ThermEng

[10] Mann BS. (1999) Solid-particle erosion and protective layers for steam turbine blading. Wear; 224: p. 8-12.
[11] Totten, G. E., \& Liang, H. (2004). Mechanical Tribology. (Dekker, Ed.) Seattle, Washington, USA: Marcel Dekker Inc.

[12] N. Eliaz, G. Shemesh, R.M. Latanision (2002), Hot corrosion in gas turbine components, Eng. Fail. Anal. 9 p. 31-43.

[13] S. Kumari, D.V.V. Satyanarayana, M. Srinivas, (2014), Failure analysis of gas turbine rotor blades, Eng. Fail. Anal. 45, p. 234-244.

[14] T. Singh, S.N. Tiwari, G. Sundararajan (1991), Room temperature erosion behaviour of 304, 316 and 410 stainless steels, Wear 145, p. $77-100$. 